\title{
Glutathione S-Transferase Mu 1
}

National Cancer Institute

\section{Source}

National Cancer Institute. Glutathione S-Transferase Mu 1. NCI Thesaurus. Code C18290.

Glutathione S-transferase Mu 1 (218 aa, $26 \mathrm{kDa}$ ) is encoded by the human GSTM1 gene. This protein is involved in the metabolism of small molecules and xenobiotics. 